\title{
The Content and In Vivo Metabolism of Gibberellin in Apple Vegetative Tissues
}

\author{
Xiaohua Yang1 \\ Department of Horticulture, Cornell University, Ithaca, NY 14850 \\ Susan K. Brown \\ Department of Horticulture and Department of Plant Breeding and Genetics, Cornell University, \\ Ithaca, NY 14850 \\ Peter J. Davies \\ Department of Horticulture and Department of Plant Biology, Cornell University, Ithaca, NY 14850
}

\begin{abstract}
Additional index words. Malus domestica, plant hormone, dwarf, stem elongation, breeding
Abstract. Despite the demonstrated importance of gibberellins (GAs) as regulators of fruit tree stature, information on their in vivo metabolism in apple vegetative tissues is still lacking. To determine whether the GA content and metabolism differs between dwarf and standard phenotypes and the influence of rootstocks, $\left[{ }^{14} \mathrm{C}\right] \mathrm{GA} \mathrm{A}_{12}$, a common precursor of all GAs in higher plants, was applied to vigorously growing apple (Malus $\times$ domestica) shoots collected from the scion cultivar Redcort on MM.106, a growth-promoting rootstock, and dwarf and standard seedlings on their own roots from progeny 806 (a cross between a breeding selection with reduced stature and an advanced breeding selection with a standard tree form). Twenty-one metabolites were identified by high-performance liquid chromatography (HPLC) and used as tracers for the purification of endogenous GAs. The existence of endogenous and $\left[{ }^{2} H\right]-l a b e l e d ~ G A_{12}, G_{15}$, $\mathbf{G A}_{53}, \mathbf{G A}_{44}, \mathbf{G A}_{19}, \mathbf{G A}_{20}$, and $\mathbf{G A}_{3}$ was demonstrated by gas chromatography-mass spectrometry (GC-MS); GA 20 was the major $\mathrm{GA}$ present, with slightly less $\mathrm{GA}_{19}$ and $\mathrm{GA}_{44}$, and with $\mathrm{GA}_{3}$ present at approximately one-third the level of $\mathbf{G A}_{20}$. Despite specific searching, neither $\mathbf{G A}_{4}, \mathbf{G A}_{7}, \mathbf{G A}_{1}$, nor $\mathbf{G A}_{29}$ was found, showing that $\left[{ }^{14} \mathrm{C} \mathrm{GA}_{12}\right.$ is metabolized mainly through the 13-hydroxylation pathway and that $\mathrm{GA}_{3}$ is a bioactive $\mathrm{GA}$ in apple vegetative tissues. The invigorating rootstock led to a slow GA metabolic rate in 'Redcort'. For self-rooted plants, the same GAs were identified in dwarf and standard seedlings from progeny 806, although standard plants metabolized at twice the speed of dwarf plants. Young branches of dwarf 806 plants treated with $\mathbf{G A}_{3}$ were one-third longer with more nodes but similar in internode length. We conclude that the dwarf phenotype in progeny 806 is not caused by a lack of certain GAs in the GA biosynthesis pathway downstream of $\mathrm{GA}_{12}$.
\end{abstract}

Apple trees with small stature are desired for high-density planting and an early transition from juvenility to production (Miller and Tworkoski, 2003). Compared with their standard counterparts, dwarf apple trees have better light penetration, which leads to more efficient photosynthesis and better fruit quality. They also require less pruning and training and are easier to harvest (El-Sharkawy et al., 2012). Commercially grown apple trees are comprised of genetically distinct parts, the scion and the rootstock. Therefore, a reduction of vigor can be achieved either by using dwarfing rootstocks or dwarf scion cultivars (genetic dwarf). Although breeding efforts focused on rootstocks for vigor and architecture control, more breeders are interested in scion breeding for the same purpose (Brown, 2012; Byrne, 2012).

Dwarf apple plants occur naturally in certain breeding populations. Alston (1976) characterized early dwarf, crinkle dwarf, and sturdy dwarf in apple breeding populations, and Steffens et al. (1989a) identified a thermo-sensitive dwarf phenotype from a hybrid population of 'Goldspur' Delicious $\times$ 'Redspur' Delicious. A breeding selection with reduced stature and reduced internodes (Selection 1, 'Fuji' $\times$ Co-op 18)

Received for publication 14 Dec. 2012. Accepted for publication 7 Mar. 2013. We thank Dr. Lailiang Cheng for providing the material 'Redcort'/MM.106 and for suggesting the presence of phlorizin.

This work is part of that submitted by Xiaohua Yang in partial fulfillment of the requirements for the degree of $\mathrm{Ph} . \mathrm{D}$.

${ }^{1}$ Corresponding author. E-mail: pjd2@cornell.edu. was identified in the breeding populations at Cornell University. Selection 1 is able to flower and set fruit, a feature rarely seen in reduced vigor scion types and crucial for genetic studies and scion breeding. A cross between Selection 1 and a parent with good fruit quality and standard tree form generated progeny 806 , which had a clear segregation of dwarf plants $(13 \%)$ in the first growing season.

The small stature of these dwarf plants, their reduced internode length, and dark foliage are very similar to plants with defects in GA biosynthesis or response. GAs affect many aspects of plant growth and development and are best known for their significant effects on internode elongation in dwarf and rosette species (Davies, 2010). Most mutants deficient in GA biosynthesis are characterized by shorter stature and darker green leaves in comparison with wild-type plants. Mutants impaired in GA signaling resemble GA biosynthesis mutants except that they cannot be rescued by GA application (Davies, 2010). In apple, GAs are also known to be involved in seed dormancy removal (Halińska and Lewak, 1987; Lewak, 2011; Oyama et al., 1996; Sinska and Lewak, 1970, 1977), inhibition of flower initiation and biennial bearing (Guitton et al., 2012; Kittikorn et al., 2010; Lang, 1990; Looney et al., 1985; Ramírez et al., 2004; Schmidt et al., 2010; Steffens et al., 1992; Stephan et al., 1999; Tromp, 1982) as well as fruit development (Curry, 2012; Di Lella et al., 2006). The investigation of GA content in apple often leads to varied results among different groups as 
a result of different cultivars and developmental stages examined as well as techniques used (Table 1) and evidence for GA metabolism in vegetative tissues of apple in vivo is still lacking.

Genes regulating key steps in GA synthesis have also been investigated in apple and are shown to be tissue-specific. In 'Fuji' apple, MdGA20ox1 [GA-20oxidase (catalyzes the sequential oxidation of $\mathrm{GA}_{53}$ to $\mathrm{GA}_{20}$ )] primarily functions in immature seeds (Kusaba et al., 2001; Zhao et al., 2010), whereas MdGA3ox1 [GA-3oxidase (catalyzes the final step in the synthesis of bioactive GAs)] and MdGA2ox1 [GA-2oxidase (a major catabolic enzyme that produces biologically inactive GAs)] are expressed primarily in flowers (Zhao et al., 2010). Steffens and Hedden (1992a) suggest that the enzymatic activity of GA-20oxidase is subject to temperature regulation, leading to dwarf plants with short internodes in ramped temperature regime $\left(20-30-20{ }^{\circ} \mathrm{C}\right)$. DELLA proteins, named for the conserved order of aspartic acid (D), glutamic acid (E), leucine (L), and alanine (A) at the N-terminus, are negative regulators of the GA signaling pathway (Sponsel and Hedden, 2010). Six endogenous DELLA proteins were identified in apple (Foster et al., 2007) and there is a significant conservation of gene function between DELLA proteins from apple and arabidopsis [Arabidopsis thaliana (Zhu et al., 2008)]. MdGAI (GA-insensitive), an innate DELLA protein of apple, was identified in both vegetative and reproductive tissues in 'Lujia 5' (Liang et al., 2011) and its mRNA moved both upstream and downstream in grafted apple trees (Xu et al., 2010).

Although dwarfing rootstocks are used commercially to reduce the vigor of apple scion cultivars, the exact interaction between scions and rootstocks is still unclear and research results may be contradictory (Bulley et al., 2005; Costes and García-Villanueva, 2007; Costes et al., 2006; Seleznyova et al., 2003; van Hooijdonk et al., 2005). It has been suggested that the supply of root-produced $\mathrm{GA}_{19}$ to shoot apices of the scion is limited by dwarfing apple rootstocks. Dwarfing interstock M.9 was also shown to limit the supply of $\left[{ }^{3} \mathrm{H}\right] \mathrm{GA}_{4}$ to the shoot tips of scion cultivar as compared with MM.115 interstock, which is non-dwarfing (Richards et al., 1986). Bulley et al. (2005) demonstrated that when the level of bioactive GAs in the scion cultivar Greensleeves was reduced by the down-regulation of GA-20oxidase, the dwarfing effect was not corrected by grafting the scion onto an invigorating rootstock MM.106 or M.25. How in vivo metabolism of GA in scion cultivars is affected by rootstocks is not known.

This study was designed to determine whether apple tree morphology could be related to the content or metabolism of gibberellins. We examined the metabolic pathway of GA in apple vegetative tissues by applying radioactive $\left[{ }^{14} \mathrm{C}\right] \mathrm{GA}_{12}$, a common precursor of all GAs in higher plants, to the base of vigorously growing shoot tips and following the subsequent production of downstream GA metabolites. The major metabolism pathway and endogenous GAs were identified using GC-MS. Metabolism of $\left[{ }^{14} \mathrm{C}\right] \mathrm{GA}_{12}$ was compared between dwarf and standard plants as well as self-rooted plants and plants on vigorous rootstocks.

\section{Materials and Methods}

Plant material. Vigorous apple shoots were collected in June 2011 from the cultivar Redcort on growth-promoting rootstock MM.106 in the Ithaca, NY, orchard for the examination of $\mathrm{GA}_{12}$ metabolism and GA identification. Progeny 806 was generated in 2007 by crossing Selection 1 ('Fuji' $\times$ Co-op 18), which has reduced stature resulting from shorter internodes with an advanced breeding selection that has good fruit quality and a standard tree form. Seeds harvested in 2007 were stratified in the refrigerator for $90 \mathrm{~d}$ and planted in pots in the greenhouse in Jan. 2008 with a day temperature of $21^{\circ} \mathrm{C}$ and night temperature $17{ }^{\circ} \mathrm{C}$. Seedlings on their own roots were later transplanted into an orchard in Geneva, NY. Vigorously growing shoots were collected from both standard and dwarf phenotypes in May 2010, their third growing season, for GA biosynthesis pathway comparison.

$\left[{ }^{14} \mathbf{C}\right] \mathbf{G A}_{12}$ SYNTHESIS. $\left[{ }^{14} \mathrm{C}\right] \mathrm{GA}_{12}$ was synthesized from $\left[{ }^{14} \mathrm{C}\right]$ mevalonic acid [custom made by Amersham (now GE Life Sciences), Piscataway, NJ] using a pumpkin (Cucurbita maxima) endosperm extract by Halińska et al. (1989) and purified by solid phase extraction (Strata-X SPE; Phenomenex, Torrance, $\mathrm{CA}$ ) and high-performance liquid chromatography (HPLC) (Davies et al., 1986). The $\left[{ }^{14} \mathrm{C}\right] \mathrm{GA}_{12}$ contained eight ${ }^{14} \mathrm{C}$ atoms per $\mathrm{GA}_{12}$ molecule (Zhu et al., 1988). The identity of the $\left[{ }^{14} \mathrm{C}\right] \mathrm{GA}_{12}$ fraction from HPLC was confirmed using GC-MS (data not shown).

$\left[{ }^{14}\right.$ C]GA 12 Application. Shoots $\approx 25 \mathrm{~cm}$ in length were harvested in the orchards and brought to the laboratory within 15 min with the cut ends of the stems submerged in water. They were cut under water just above the third fully expanded leaf below the apex. Samples were 5 to $10 \mathrm{~cm}$ in length and weighed 1.5 to $4.5 \mathrm{~g}$ (seedlings from progeny 806 and 'Redcort', respectively). The base of the cut stem of each sample was placed in a $1.5-\mathrm{mL}, \mathrm{V}$-shaped-bottomed, polystyrene vial with treatment solution. For shoots from 'Redcort', each vial contained $0.5 \mathrm{~mL}$ of water with $7.4 \mathrm{GBq}\left[{ }^{14} \mathrm{C}^{-\mathrm{GA}_{12}}\right.$ [560 pmol, $190 \mathrm{ng}$ (Zhu et al., 1988)]. Cuttings were maintained under fluorescent lamps at 77 $\mu \mathrm{mol} \cdot \mathrm{m}^{-2} \cdot \mathrm{s}^{-1}$ for $30 \mathrm{~min}, 1,3,6$, or $48 \mathrm{~h}$, with three replicates for each time period. Water in $0.5-\mathrm{mL}$ aliquots was added when the vials were nearly empty. Uptake occurred at an average rate of $\approx 1 \mathrm{~mL} \cdot \mathrm{h}^{-1}$, although this varied with shoot vigor. The shoots in the 48-h treatment were placed together in a $100-\mathrm{mL}$ beaker with water after they had been in the vial for $12 \mathrm{~h}$. For shoots from progeny 806 , each vial contained $0.5 \mathrm{~mL}$ of water with $3.7 \mathrm{GBq}$ $\left[{ }^{14} \mathrm{C}\right] \mathrm{GA}_{12}(280 \mathrm{pmol}, 95 \mathrm{ng})$. Cuttings were left in the same light (intensity as previously described) for $15 \mathrm{~min}, 30 \mathrm{~min}, 1,3,6,12$, 24 or $48 \mathrm{~h}$ with two replicates at each time period. Water in $0.5-\mathrm{mL}$ aliquots was added when the vials were nearly empty. The shoots in the 24- and 48-h treatment were placed in a 100-mL beaker with water after they had been in the vial for $12 \mathrm{~h}$. After the treatments, the shoots were frozen in liquid nitrogen and stored at $-80{ }^{\circ} \mathrm{C}$ until extraction. Each experiment was conducted twice for both the standard and dwarf plants.

GibBEREllin EXTRACTION AND PURIFICATION. All solvents used were HPLC grade. Glassware was baked at $500{ }^{\circ} \mathrm{C}$ to destroy any contaminating GAs and then silanized with siliconizing fluid (AquaSil; Pierce Biotechnology, Rockford, IL). Each frozen shoot tip was individually placed in $20 \mathrm{~mL}$ icecold $80 \%$ (v/v) $\mathrm{MeOH}$ and ground with a $2-\mathrm{cm}$ head (Polytron; Brinkmann Instruments, Westbury, NY), which was rinsed twice with $80 \%(\mathrm{v} / \mathrm{v}) \mathrm{MeOH}$. The rinses were combined with the extract. The homogenate was left overnight at $4{ }^{\circ} \mathrm{C}$ before vacuum filtration through filter paper (Whatman, Piscataway, NJ) with a pad of filter aid (Highflo Super Cel; Sigma-Aldrich, St. Louis, MO) followed by a three-pad volume rinse of $80 \%(\mathrm{v} / \mathrm{v})$ $\mathrm{MeOH}$. The filtrate volume was reduced on a rotary evaporator at $36{ }^{\circ} \mathrm{C}$ to partially remove the $\mathrm{MeOH}$. One milliliter $\mathrm{NH}_{4} \mathrm{OH}$ 
Table 1. Gibberellins (GAs) previously identified in apple.

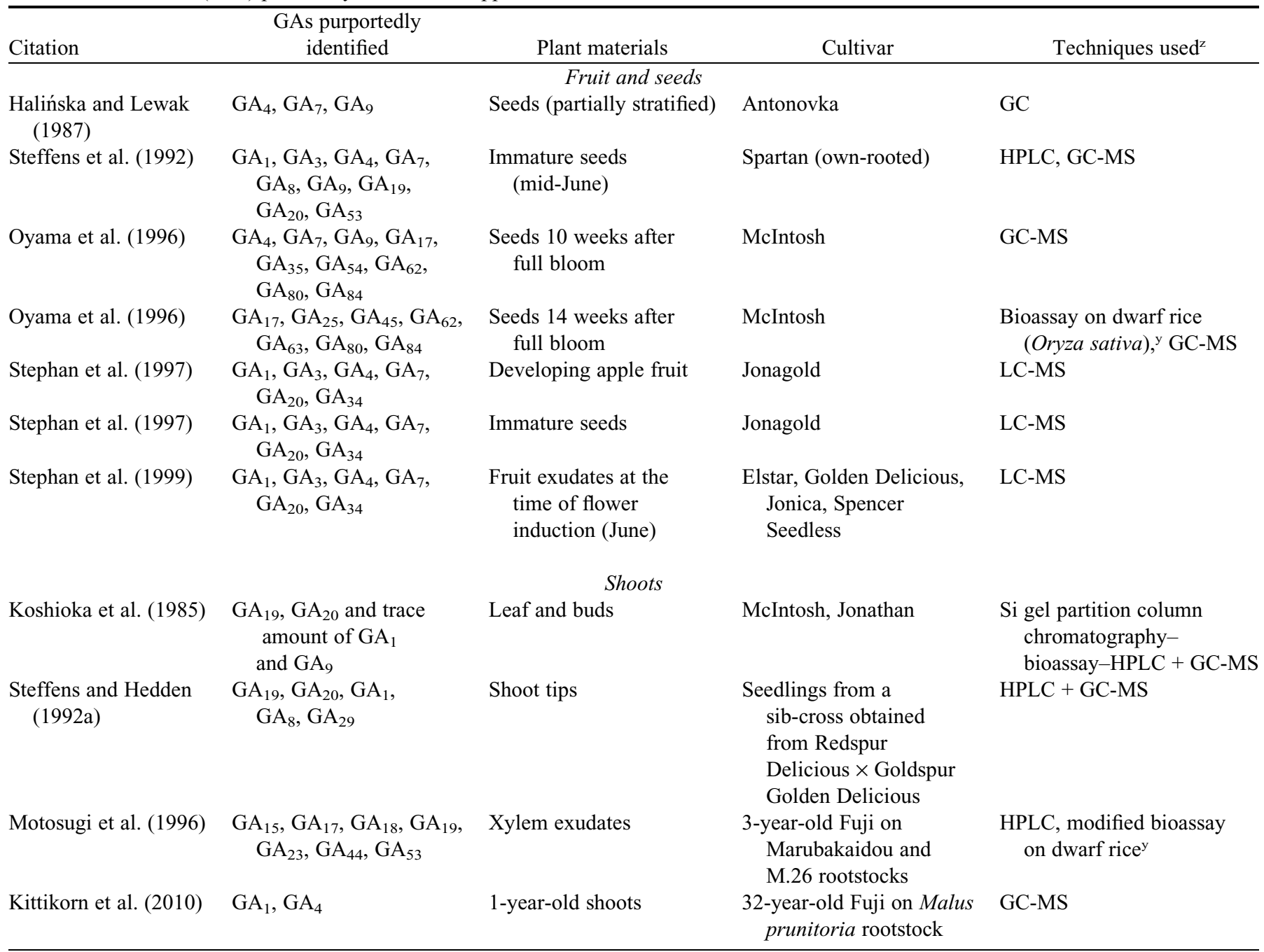

${ }^{\mathrm{z} O n l y}$ gas chromatography-mass spectroscopy (GC-MS) or liquid chromatography-MS (LC-MS) provides unequivocal evaluation.

${ }^{y}$ High-performance liquid chromatography (HPLC) and bioassay alone provides only an indication of hydrophobicity of the GA. Because GA 17 is not biologically active, it cannot be found by bioassay.

and $20 \mathrm{~mL}$ hexanes were then added to each sample and the mix was shaken vigorously to partition the chlorophyll into the hexanes. Then evaporation was resumed to precipitate chlorophyll on the removal of the hexanes and then until all the $\mathrm{MeOH}$ was removed and the volume was reduced to $\approx 20 \mathrm{~mL}$. The sample was acidified to $\mathrm{pH} 3$ to 3.5 with acetic acid and vacuumfiltered through filter aid with a two-pad volume rinse of acidified water $[0.2 \%$ acetic acid (v/v), $\mathrm{pH} 3.5]$.

A 6-mL Strata-X SPE cartridge was washed with $5 \mathrm{~mL}$ of $100 \% \mathrm{MeOH}$ and $10 \mathrm{~mL}$ of acidified $\mathrm{H}_{2} \mathrm{O}$. The sample was loaded through the reservoir on top of the cartridge. The cartridge was first washed with flask rinse and $2 \mathrm{~mL}$ of acidified water with the eluate discarded and then with $4 \mathrm{~mL} 100 \%$ $\mathrm{MeOH}$. The eluate was collected in a $4.5-\mathrm{mL}$ polystyrene tube and stored in the freezer until further use.

To remove phlorizin, which caused major problems because of precipitation, especially in the HPLC injector and columns, a combination of reverse phase/anion exchange solid phase extraction cartridges (Strata-X-A and Strata-XL-A; Phenomenex) was used. These cartridges were washed with $1 \mathrm{~mL}$ $\mathrm{MeOH}$ and equilibrated with $1 \mathrm{~mL}$ water. Samples were diluted to less than $20 \%(\mathrm{v} / \mathrm{v}) \mathrm{MeOH}$ and buffered to $\mathrm{pH} 6$ to 7 . Then they were loaded to the reservoir on top of the Strata-XL-A cartridge and drawn through by vacuum. The eluate was then loaded to Strata-X-A and vacuum filtered through to ensure the capture of all the wanted GAs. Both columns were washed with $25 \%(\mathrm{v} / \mathrm{v})$ ammonium acetate followed by $100 \% \mathrm{MeOH}$; the eluate, containing the phlorizin, was discarded. Lastly, both cartridges were washed with $5 \%(\mathrm{v} / \mathrm{v})$ formic acid and then $4 \mathrm{~mL} \mathrm{100 \%} \mathrm{MeOH}$. The MEOH eluate, containing the GAs, was combined and stored at $-20{ }^{\circ} \mathrm{C}$ until further use.

HPLC PURIFICATION. Each sample was evaporated to dryness under $\mathrm{N}_{2}$ at $37^{\circ} \mathrm{C}$ and the container was rinsed with $0.1 \mathrm{~mL}$ $\mathrm{MeOH}$ and transferred to a centrifugal nylon membrane filter tube (0.45- $\mu \mathrm{m}$; Corning Spin-x, Lowell, MA) followed by two further rinses of $0.3 \mathrm{~mL}$ of $\mathrm{H}_{2} \mathrm{O}$ with $0.2 \%(\mathrm{v} / \mathrm{v})$ acetic acid. The solution was then filtered by centrifuging at $3500 g_{\mathrm{n}}$ for $5 \mathrm{~min}$. Each sample of $\approx 0.7 \mathrm{~mL}$ was loaded onto an analytical C18 HPLC column (Synergi 4u Hydro-RP 80A; Phenomenex) using a $1-\mathrm{mL}$ injection loop and run at $1 \mathrm{~mL} \cdot \mathrm{min}^{-1}$ in a $\mathrm{H}_{2} \mathrm{O}[\mathrm{A}$ (containing $2 \mathrm{~mL} \cdot \mathrm{L}^{-1}$ glacial acetic acid)] to acetonitrile (B) gradient. The gradient used (all by volume) was: $27 \%$ B for 2 
$\min , 27 \%$ to $33 \% \mathrm{~B}$ over $5 \mathrm{~min}, 33 \%$ to $35 \% \mathrm{~B}$ over $4 \mathrm{~min}, 35 \%$ to $70 \% \mathrm{~B}$ over $15 \mathrm{~min}, 75 \%$ to $100 \% \mathrm{~B}$ over $5 \mathrm{~min}$, and holding at $100 \% \mathrm{~B}$. The column eluate passed through an in-line radioactivity monitor (Trace 7140; Packard, Downers Grove, IL) equipped with a flow cell packed with insoluble scintillator beads ( $170 \mu \mathrm{L}$ void volume). The efficiency of the monitor was $\approx 10 \%(\mathrm{v} / \mathrm{v})$ for ${ }^{14} \mathrm{C}$. An automatic peak-detection circuit controlled a fraction collector (Ultrorac; LKB, Bromma, Sweden) and collected each individual peak for all the samples.

IDENTIFICATION OF GC RETENTION TIME (RT) FOR GIBBERELLINS WITH $\left[{ }^{2} \mathbf{H}\right]$ STANDARDS. $\left[{ }^{2} \mathrm{H}\right] \mathrm{GA}$ standards $\left(\mathrm{GA}_{1}\right.$, $\mathrm{GA}_{3}, \mathrm{GA}_{4}, \mathrm{GA}_{7}, \mathrm{GA}_{8}, \mathrm{GA}_{9}, \mathrm{GA}_{12}, \mathrm{GA}_{15}, \mathrm{GA}_{19}, \mathrm{GA}_{20}, \mathrm{GA}_{29}$, $\mathrm{GA}_{34}, \mathrm{GA}_{44}$, and $\mathrm{GA}_{53}$ ) were obtained from L. Mander [Australian National University, Canberra, Australia (synthesized by T. Herlt)]. GA aliquots were methylated with a surplus of freshly synthesized ethereal diazomethane. The mixture was then dried using $\mathrm{N}_{2}$ and re-dissolved in $\mathrm{MeOH}$ to reach a stock concentration of $1 \mathrm{ng} \cdot \mu \mathrm{L}^{-1}$ for each GA. Fifty microliters (50 ng of each GA) was transferred to 1-mL tapered glass vials (Chromcol; Fisher, Sun SRi, Rockwood, TN). It was then thoroughly redried with a stream of $\mathrm{N}_{2}$ and dissolved in $2 \mu \mathrm{L}$ pyridine and $10 \mu \mathrm{L}$ bis-trimethylsilyltrifluoroacetamide containing $1 \%(\mathrm{v} / \mathrm{v})$ trimethylchlorosilane (Supelco, Bellefonte, PA). After $40 \mathrm{~min}$ in an oven at $80{ }^{\circ} \mathrm{C}$, GC-MS analyses were performed with gas chromatograph (5890A; Hewlett-Packard, Palo Alto, CA) connected to a 5970B Mass Selective Detector (Hewlett-Packard). Samples $(1 \mu \mathrm{L})$ were injected without splitting onto a $20 \mathrm{~m} \times 0.18 \mathrm{~mm} \times 0.18-\mu \mathrm{m}$ column (Zebron ZB-5MS, 7FD-G010-08; Phenomenex). The temperature program for the $\mathrm{GC}$ was injection at $60^{\circ} \mathrm{C}$, increasing to $240^{\circ} \mathrm{C}$ at $30{ }^{\circ} \mathrm{C} \cdot \mathrm{min}^{-1}$, to $275^{\circ} \mathrm{C}$ at $4{ }^{\circ} \mathrm{C} \cdot \mathrm{min}^{-1}$, and finally to $325^{\circ} \mathrm{C}$ at $30{ }^{\circ} \mathrm{C} \cdot \mathrm{min}^{-1}$. The injection of the mixture was analyzed in selected ion monitoring (SIM) mode to monitor the most abundant ion (at +2 mass units from the base peak for $\left[{ }^{12} \mathrm{C}\right] \mathrm{GA}$ ) for each GA (Gaskin and MacMillan, 1991). When needed for confirmation, six ions per GA were monitored. Retention time obtained for each GA standard was used to adjust the GC program to monitor specific GAs at specific time windows to increase sensitivity. The standard mixture was run at the start of each day before the analysis of apple samples.

IDENTIFICATION OF ENDOGENOUS GIBBERELLINS USING GC-MS. The same GA HPLC peaks from different apple samples were bulked together and methylated with a surplus of ethereal diazomethane. The methylated samples were re-chromatographed using the analytical column and the same gradient (described previously). This provided an extra purification, because the retention time of the methylated compounds was later than the non-methylated GAs.

Samples were dried and re-dissolved in $\mathrm{MeOH}$ before transfer to 1-mL tapered glass vials and derivatized as described before. Each sample ( $1 \mu \mathrm{L})$ was injected on to GC-MS without splitting and run under the temperature program as the standard mixture. The first injection of each sample was under the SIM mode to monitor the most abundant native ion for each GA and the ion at plus $-16 \mathrm{~m} \cdot \mathrm{z}^{-1}$ (allowing for the eight $\left[{ }^{14} \mathrm{C}\right]$ atoms per GA derived from the fed molecule) at the specific time window for each of the GAs for which we had standards (as listed previously). After preliminary results were obtained, a second injection monitoring more native ions from the GA spectrum was used to confirm the identity of the GA.

GA $_{3}$ TREATMENT. Fifteen control branches and 11 treatment branches were selected from 806 dwarf plants for a $\mathrm{GA}_{3}$ application. Control and treatment solutions were applied to the same plant on different comparable branches. Solutions containing less than $1 \%$ ethanol and $0.1 \%(\mathrm{v} / \mathrm{v})$ Tween-20 with or without $\mathrm{GA}_{3}$ (Sigma-Aldrich) were brushed on both sides of newly grown leaves of the uppermost shoots until they were fully covered with a thin film. Applications were made weekly for 5 consecutive weeks starting on 29 July 2010.

Stem elongation above the node originally located immediately below the terminal bud of each branch was measured on the day of the third and fifth applications and 2 weeks after the fifth application. Node number of elongated sections was determined. Data were submitted to Student's $t$ test for comparison at $\alpha=0.05, \mathrm{df}=24$ with $\mathrm{JMP} 9{ }^{\circledR}$ (SAS Institute, Cary, NC).

\section{Results}

Metabolites of $\left[{ }^{14} \mathrm{C}\right] \mathrm{GA}_{12}$ IN 'RedCORT'/MM.106. Sixteen metabolites of $\left[{ }^{14} \mathrm{C}\right] \mathrm{GA}_{12}$ were identified in 'Redcort'/MM.106. Generally, GA metabolism produces compounds of increasing polarity and as the metabolism progresses more polar compounds are produced and elute from the HPLC (Davies et al., 1986). The feeding material $\left[{ }^{14} \mathrm{C}\right] \mathrm{GA}_{12}$ was the last compound to elute. For convenience, major metabolites were designated with the letters A to U, corresponding to increasing polarity (Fig. 1).

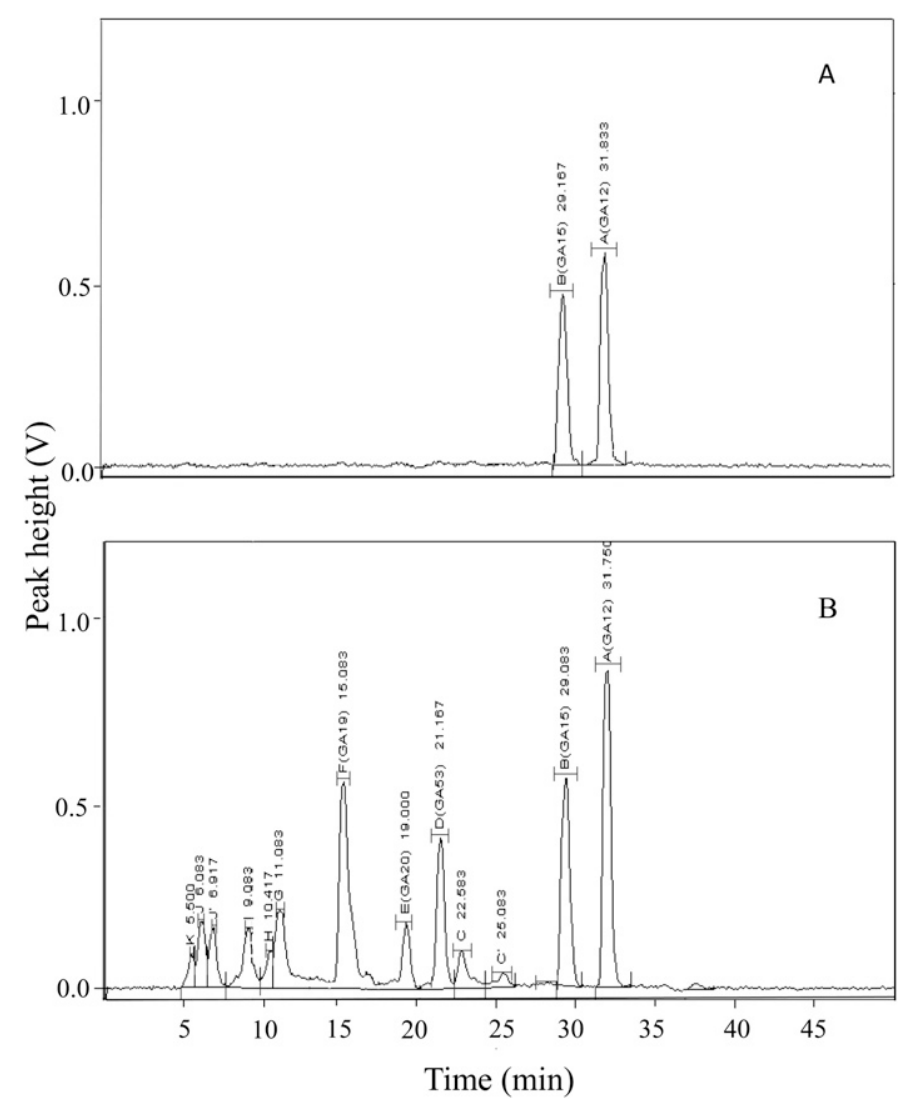

Fig. 1. High-performance liquid chromatographs of metabolites of $\left[{ }^{14} \mathrm{C}\right] \mathrm{GA}_{12}$ in cultivar Redcort/MM.106 apple shoots at $30 \mathrm{~min}(\mathbf{A})$ and $48 \mathrm{~h}$ (B) after feeding with $\left[{ }^{14} \mathrm{C}\right] \mathrm{GA}_{12}$ through the base of the shoots. The detector response, indicating the amount of radioactivity, is in volts. Peaks are labeled with retention time and the gibberellins identified by gas chromatography-mass spectroscopy. 
Fifty percent of the $\left[{ }^{14} \mathrm{C}\right] \mathrm{GA}_{12}$ feeding material (peak $\mathrm{A}$, $\left.\mathrm{GA}_{12}\right)$ was metabolized quickly into peak $\mathrm{B}\left(\mathrm{GA}_{15}\right)$ at $30 \mathrm{~min}$ (Figs. 1A and 2A). Other early metabolites started to be synthesized at $1 \mathrm{~h}$. At $48 \mathrm{~h}, 13$ of the 16 metabolites detected in 'Redcort' were evident in the HPLC chromatograph (Figs. 1B and 2A) and the major metabolites included peaks L $\left(\mathrm{GA}_{19}\right), \mathrm{G}\left(\mathrm{GA}_{53}\right)$, I $\left(\mathrm{GA}_{20}\right), \mathrm{A}\left(\mathrm{GA}_{12}\right)$, and $\mathrm{B}\left(\mathrm{GA}_{15}\right)$. The initial appearance and trend of certain metabolites may have been missed, because samples were not collected between 6 and $48 \mathrm{~h}$.
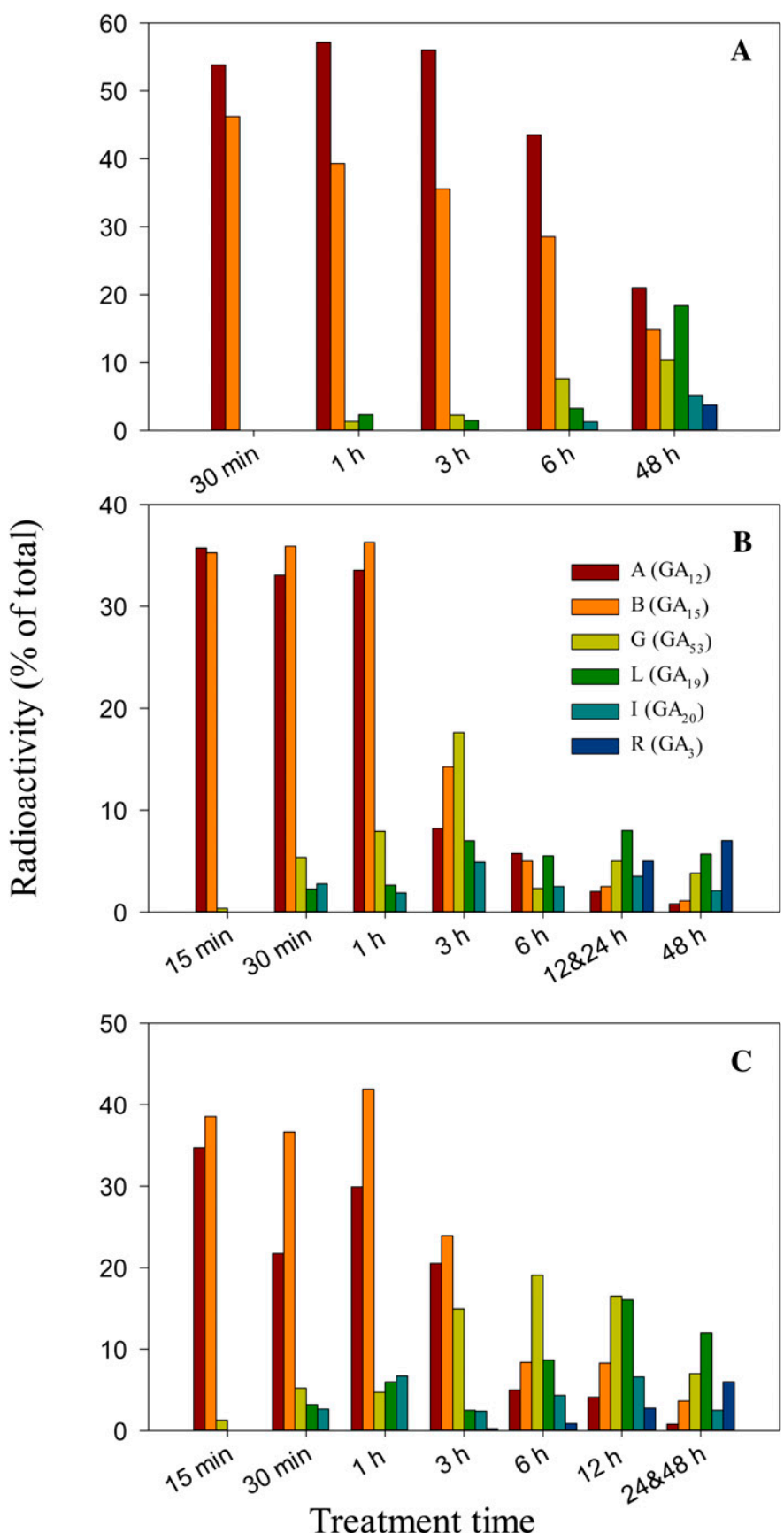

Fig. 2. Metabolites of $\left[{ }^{14} \mathrm{C}\right] \mathrm{GA}_{12}$ measured using high-performance liquid chromatography (HPLC) in shoots of apple cultivar Redcort/MM.106 (A), 806 standard plants $(\mathbf{B})$, and 806 dwarf plants $(\mathbf{C})$ at different times after the start of feeding the $\left[{ }^{14} \mathrm{C}\right] \mathrm{GA}_{12}$ to the base of the shoots; only those metabolites identified as containing gibberellin using gas chromatography-mass spectroscopy are shown. Radioactivity was calculated by HPLC peak area.
A brown oily fraction appeared at the bottom of the containers on sample concentration or sometimes instead a heavy yellow precipitate formed on lowering the methanol content of the sample. This was identified as phlorizin from its appearance, solubility, and ethyl acetate partitioning characteristics (Gmelin, 1849; Gosch et al., 2010). The supernatant of the concentrated sample was labeled Sample 1, and the bottom fraction that went through phlorizin removal using reverse phase/anion exchange solid phase extraction cartridges was labeled Sample 2. Metabolites O, P, Q, R $\left(\mathrm{GA}_{3}\right)$, and S were all missing in Sample 2 (Fig. 3). Peak T, detected in individual 48-h HPLC samples, was not found in either sample, possibly as a result of its small quantity. Peaks $\mathrm{C}\left[\mathrm{GA}_{44}\right.$, retention time (Rt) 27.92], E (Rt 24.5), and H (Rt 20.00) were only detected in Sample 2 but not in Sample 1 nor were they detected in individual samples collected from each time point.

These two samples were methylated and further analyzed by HPLC. Twelve methylated metabolites were detected in Sample 1 and nine in Sample 2. Because the difference between the two protocols is the removal of non-acidic samples using Strata-XA in the preparation of Sample 2, it is likely that the additional compounds in Sample 1 represented GA conjugates with Sample 2 containing only the free GAs; it is unknown why $\mathrm{GA}_{3}$ was lost in Sample 2 .

IDENTIFICATION OF ENDOGENOUS GIBBERELLINS WITH GC-MS. The endogenous GAs were copurified with the $\left[{ }^{14} \mathrm{C}\right] \mathrm{GAs}$ by following the radioactive peaks. Detection was then achieved by GC-MS and searching for the appropriate ions of the endogenous and $\left[{ }^{14} \mathrm{C}\right] \mathrm{GAs}$ at the retention times of each $\left[{ }^{2} \mathrm{H}\right] \mathrm{GA}$ standard. Endogenous $\mathrm{GA}_{12}, \mathrm{GA}_{15}, \mathrm{GA}_{53}, \mathrm{GA}_{44}, \mathrm{GA}_{19}, \mathrm{GA}_{20}$, and $\mathrm{GA}_{3}$ (in that metabolic order) [Fig. 4 (molecular structures in Supplementary Fig. 1)] were present in 'Redcort' apple shoots (Tables 2 and 3). The relative HPLC elution times of these GAs were consistent with results from Koshioka et al. (1983). The

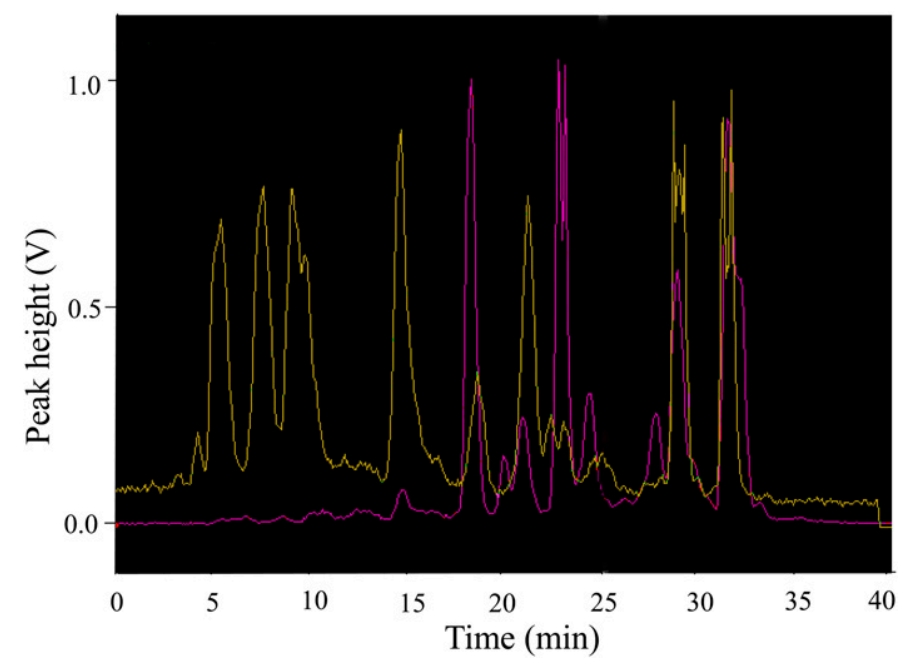

Fig. 3. Overlay high-performance liquid chromatography of metabolites of $\left[{ }^{14} \mathrm{C}\right] \mathrm{GA}_{12}$ in cultivar Redcort/MM.106 apple shoots showing the results of the removal of neutral compounds using mixed-function reverse-phase/anionexchange solid-phase-extraction cartridges (Strata-X-A; Phenomenex, Torrance, CA): total (yellow) and after removal of neutral compounds (magenta). The detector response, indicating the amount of radioactivity, is in volts. Samples collected at different times of $\left[{ }^{14} \mathrm{C}\right] \mathrm{GA}_{12}$ feeding experiment were bulked together. The multiple appearing peaks on the three tallest peaks to the right are the result of detector scale reset and represent only a single peak. 
native and ${ }^{14} \mathrm{C}$ mass ions for all the GAs for which $\left[{ }^{2} \mathrm{H}\right] \mathrm{GAs}$ were available were checked in every appropriate HPLC fraction. Despite their expected appearance, GAs 34, 9, 1, 29, and 8 were not detected, and $\mathrm{GA}_{3}$ (Fig. 5) was the only bioactive GA found in our study. There was no trace of GAs 4 and 7, the most common GAs in apple seeds and fruit.

$\mathrm{GA}_{12}$ and $\mathrm{GA}_{15}$ followed similar metabolic trends during the study. $\mathrm{GA}_{12}$ was consumed to produce $\mathrm{GA}_{15}$ and $\mathrm{GA}_{53}$, whereas the latter was metabolized further to produce the bioactive $\mathrm{GA}_{3}$. Based on the existence of $\mathrm{GA}_{20}$ and $\mathrm{GA}_{3}, \mathrm{GA}_{5}$ should also exist in 'Redcort' shoots (Sponsel and Hedden, 2010). $\mathrm{GA}_{53}$ and $\mathrm{GA}_{19}$ were both detected at $1 \mathrm{~h}$, whereas $\mathrm{GA}_{20}$ was not detected until $6 \mathrm{~h}$, an indication that $\mathrm{GA}_{19}$ to $\mathrm{GA}_{20}$ is a rate-limiting step. $\mathrm{GA}_{3}$ was first detected at $48 \mathrm{~h}$, but because no sample was collected between 6 and $48 \mathrm{~h}$, the initial appearance of $\mathrm{GA}_{3}$ could not be determined nor whether $\mathrm{GA}_{20}$ to $\mathrm{GA}_{3}$ was a fast or slow metabolic step. $\mathrm{GA}_{44}$, the intermediate between $\mathrm{GA}_{53}$ and $\mathrm{GA}_{19}$, was only detected in bulked Sample 2 of 'Redcort' but not in any samples from individual time periods, perhaps

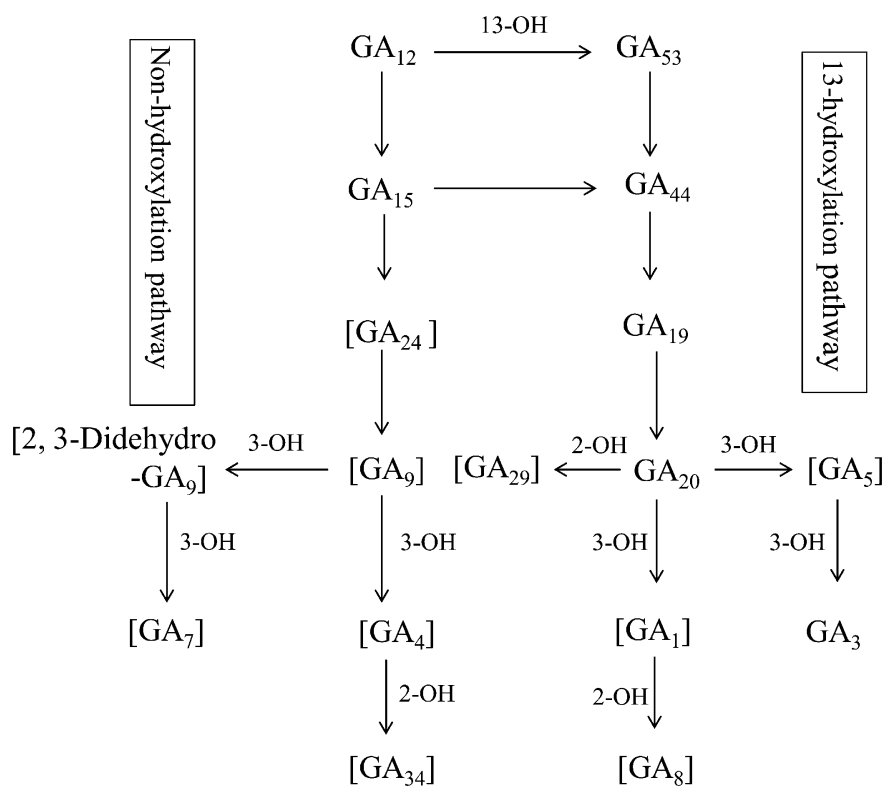

Fig. 4. The metabolic pathway of the gibberellins identified in cultivar Redcort/ MM.106 apple shoots after feeding with $\left[{ }^{14} \mathrm{C}\right] \mathrm{GA}_{12}$. Gibberellins in parenthesis were not detected in this study. a combined result of fast metabolic rate and an insufficient amount in each individual sample.

$\left[{ }^{14} C_{G} G_{12}\right.$ METABOLISM IN DWARF AND STANDARD APPLE SEEDLINGS FROM PROGENY 806. Eighteen $\left[{ }^{14} \mathrm{C}\right] \mathrm{GA}_{12}$ metabolites were identified by HPLC (Table 4). Sibling dwarf and standard progeny in 806 demonstrated similar metabolic trends (Fig. 2B-C) with more polar metabolites produced later in the time course. However, in the standard plants, GA metabolism was faster than in the dwarf plants (Fig. 6). For individual metabolites, peak N (identity unknown) (Fig. 7), which transiently existed as a principal compound in the 3-h HPLC chromatograph of standard plants, was not found at any time point in dwarf plants. Most other metabolites existed in both dwarf and standard plants but often followed different metabolic trends and existed for different durations (Fig. 8). The metabolite $\mathrm{O}$ was the dominant peak after $12 \mathrm{~h}$ in 806 standard plants. In contrast, peak $\mathrm{Q}, \mathrm{G}\left(\mathrm{GA}_{53}\right)$, and $\mathrm{L}\left(\mathrm{GA}_{19}\right)$ were all major metabolites for 806 dwarf seedlings at the second half of the time course.

Plants in 806 had a much faster metabolic rate compared with that of 'Redcort'/MM.106 (Fig. 9). For 806, GA 12 and $\mathrm{GA}_{15}$ were mostly metabolized between 1 and $6 \mathrm{~h}$. However, in 'Redcort', these two compounds were consumed at a more gradual speed with downstream metabolites also appearing later ( $1 \mathrm{~h}$ vs. $15 \mathrm{~min}$ in progeny 806 ). At the end of the study, 'Redcort' peak A and B still had significant amounts $(20.5 \%$ and $14.5 \%$, respectively), yet less than $5 \%$ was present in both 806 dwarf and standard seedlings. It is possible that these differences result from the much larger size of the 'Redcort' shoots (averaged $3.2 \mathrm{~g}$ ) because they were taken from fully grown apple trees rather than seedlings (sample averaged $2.0 \mathrm{~g}$ ). For 806 standard, $\mathrm{GA}_{53}$ peaked at $3 \mathrm{~h}$, where $\mathrm{GA}_{12}$ and $\mathrm{GA}_{15}$ were at the end of their sharp decrease. After $3 \mathrm{~h}$, the decrease of $\mathrm{GA}_{12}$ and $\mathrm{GA}_{15}$ slowed, where $\mathrm{GA}_{53}$ was quickly metabolized. The same occurred in 806 dwarf plants, just at a slower speed. However, in 'Redcort', the amount of $\mathrm{GA}_{53}$ rose from 1 to $48 \mathrm{~h}$, suggesting that $\mathrm{GA}_{53}$ always was produced faster than it was consumed.

$\mathrm{GA}_{19}$ and $\mathrm{GA}_{20}$ appeared at the same time in standard and dwarf apple progeny, which suggests $\mathrm{GA}_{19}$ was metabolized immediately to $\mathrm{GA}_{20}$. Because more $\mathrm{GA}_{19}$ was produced than consumed for $\mathrm{GA}_{20}$, the conversion from $\mathrm{GA}_{19}$ to $\mathrm{GA}_{20}$ is suggested to be regulated tightly. In 'Redcort', $\mathrm{GA}_{20}$ appeared $5 \mathrm{~h}$ later after the initial appearance of $\mathrm{GA}_{19}$ at $1 \mathrm{~h}$. From 6 to $48 \mathrm{~h}, \mathrm{GA}_{19}$ increased $\approx 15 \%$, whereas $\mathrm{GA}_{20}$ increased only $\approx 4 \%$.

Table 2. Gas chromatography-mass spectroscopy (GC-MS) identification of endogenous gibberellins (GAs) coincident on high-performance liquid chromatography (HPLC) with peaks resulting from the metabolism of $\left[{ }^{14} \mathrm{C}\right] \mathrm{GA}_{12}$ in apple shoots from cultivar Redcort/MM.106.

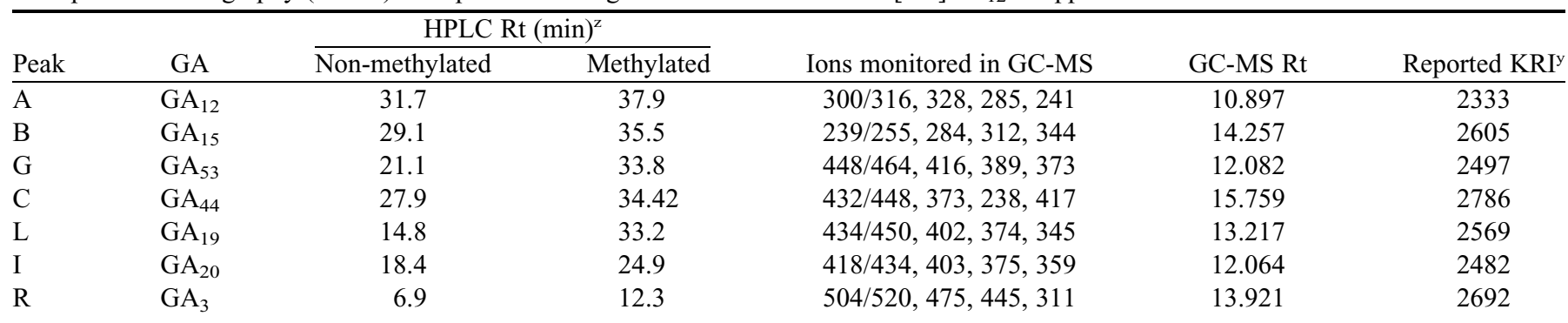

${ }^{\mathrm{z} A f t e r}$ methylation, each peak may separate to multiple methylated peaks. The retention time (Rt) for methylated peak is for the peak that was identified as a GA.

${ }^{y}$ Kovats retention index: the relative elution Rt of the GA in question compared with that of paraffins of differing lengths of carbon chain represented by the first two digits of the number, as reported in Gaskin and MacMillan (1991). 
Table 3. Relative amounts of endogenous gibberellins (GAs) in apple cultivar Redcort/MM.106 shoots derived from the relative intensities of base peak ions of ${ }^{14} \mathrm{C}:{ }^{12} \mathrm{C}$ in the mass spectra of fed $\left[{ }^{14} \mathrm{C}\right] \mathrm{GA}_{12}$ and GAs extracted from the shoots.

\begin{tabular}{lccc}
\hline Gibberellin & ${ }^{14} \mathrm{C}$ ion mass & ${ }^{12} \mathrm{C}$ ion mass & $\begin{array}{c}\text { Amount of }{ }^{12} \mathrm{C} \text { compared with the } \\
\text { proportion of }{ }^{12} \mathrm{C} \text { to }{ }^{14} \mathrm{C} \text { in the fed } \mathrm{GA}_{12}\end{array}$ \\
\hline Fed GA 12 & 316 & $300^{\mathrm{z}}$ & $\times 1.00$ \\
Extracted $\mathrm{GA}_{12}$ & 316 & 300 & $\times 1.36$ \\
Extracted $\mathrm{GA}_{15}$ & 255 & 239 & $\times 1.05^{\mathrm{y}}$ \\
Extracted $\mathrm{GA}_{53}$ & 464 & 448 & $\times 2.83$ \\
Extracted $\mathrm{GA}_{44}$ & 448 & 432 & $\times 84.9$ \\
Extracted $\mathrm{GA}_{19}$ & 450 & 434 & $\times 95.6$ \\
Extracted $\mathrm{GA}_{20}$ & 434 & 418 & $\times 106.7$ \\
Extracted $\mathrm{GA}_{3}$ & 520 & 504 & $\times 34.8$ \\
\hline
\end{tabular}

${ }^{\mathrm{z}}$ Amount of ${ }^{12} \mathrm{C}$ ion compared with ${ }^{14} \mathrm{C}$ ion in fed $\mathrm{GA}_{12}=\times 0.97$.

${ }^{\mathrm{y}}$ Value corrected for the fact that the ${ }^{14} \mathrm{C}$ base peak ion at mass 255 also occurs in the ${ }^{12} \mathrm{C}$ spectrum at $7.4 \%$.

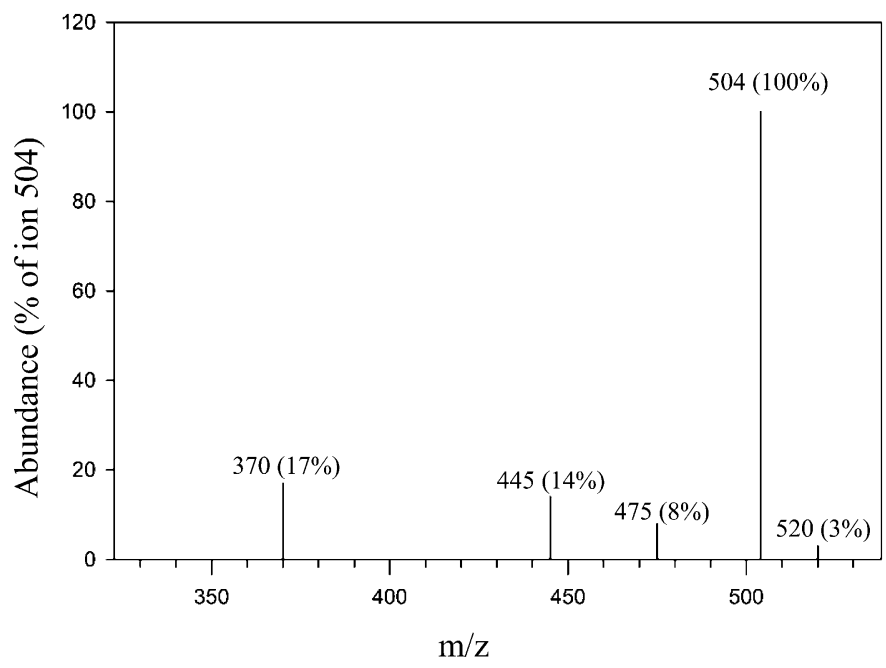

Fig. 5. Selected ion monitoring profile of extracted $\left[{ }^{12} \mathrm{C} /{ }^{14} \mathrm{C}\right] \mathrm{GA}_{3}$ derived from $\left[{ }^{14} \mathrm{C}\right] \mathrm{GA}_{12}$ fed to apple cultivar Redcort/MM.106 apple shoots after separation and detection using gas chromatography-mass spectroscopy, monitoring native ${ }^{12} \mathrm{C}$ ions at mass/charge $(\mathrm{m} / \mathrm{z}) 370,445,475,504$, and ${ }^{14} \mathrm{C}$ ion 520 . All ions peaked together (not shown).

Table 4. $\left[{ }^{14} \mathrm{C}\right] \mathrm{GA}_{12}$ metabolites identified in apple shoots of apple cultivar Redcort/MM.106 (Sample 1, total; sample 2, after the removal of neutral compounds) and progeny 806 (standard and dwarf phenotypes). ${ }^{\mathrm{z}}$

\begin{tabular}{llllll}
\hline & \multicolumn{5}{c}{ Peak } \\
\cline { 2 - 6 } & A B C D E F G H I \\
\cline { 2 - 6 } Cultivar & 121544 & 53 & 20 & 19 & 3 \\
\hline Redcort 1 & X X & X X X & X & X & X X X X X \\
Redcort 2 & X X X & X X X X X & X & \\
806 standard X X & X X X X & X X X X X X X X X X X X X \\
806 dwarf & X X & X X X X & X X X X X & X X X X X X X \\
z"X” indicates the presence of the peak on high-performance liquid \\
chromatography.
\end{tabular}

$\mathrm{GA}_{3}$ appeared in 806 dwarf plants at $3 \mathrm{~h}$ and in 806 standard plants at $12 \mathrm{~h}$. Samples were not collected between 6 and $48 \mathrm{~h}$ in 'Redcort', so the first appearance of $\mathrm{GA}_{3}$ could be earlier than the $48 \mathrm{~h}$ recorded.
GibBERELLIN TREATMENT. Based on the measurements taken 2 weeks after the fifth application, the new growth of shoots of dwarf 806 plants treated with $\mathrm{GA}_{3}$ solution was onethird longer than control branches $(P<0.027$, Student's $t$ test $)$ with more nodes $(P<0.007$, Student's $t$ test), but was similar in internode length (Table 5).

\section{Discussion}

Seven GAs, both endogenous and as metabolites of the applied $\left[{ }^{14} \mathrm{C}\right] \mathrm{GA}_{12}$, including $\mathrm{GA}_{12}, \mathrm{GA}_{15}$, $\mathrm{GA}_{53}, \mathrm{GA}_{44}, \mathrm{GA}_{19}, \mathrm{GA}_{20}$, and $\mathrm{GA}_{3}$, were identified in apple vegetative tissues after the application of radioactive $\left[{ }^{14} \mathrm{C}\right] \mathrm{GA}_{12}$ to the base of isolated shoot tips. Based on the dilution of the applied $\left[{ }^{14} \mathrm{C}\right] \mathrm{GA}^{12}$ by endogenous GAs as metabolism proceeded (Table 3 ), $\mathrm{GA}_{20}$ was the major GA present with slightly less $\mathrm{GA}_{19}$ and $\mathrm{GA}_{44}$ and with $\mathrm{GA}_{3}$ present at approximately one-third the level of $\mathrm{GA}_{20}$. $\mathrm{GA}_{12}$ is the common precursor for all GAs in higher plants and is at a branch point of the GA biosynthesis pathway, undergoing either oxidation at $\mathrm{C}-20$ to form $\mathrm{GA}_{15}$ or hydroxylation at $\mathrm{C}-13$ to produce $\mathrm{GA}_{53}$ before further oxidation at $\mathrm{C}-20 . \mathrm{GA}_{12}$ and $\mathrm{GA}_{53}$ are precursors of the non-13-hydroxylation and the 13hydroxylation pathways, respectively (Sponsel and Hedden, 2010). In shoots from the G2 line of a dwarf pea (Pisum sativum) lacking the dominant $L e$ allele that controls the conversion from $\mathrm{GA}_{20}$ to $\mathrm{GA}_{1}, \mathrm{GA}_{12}$-aldehyde (an immediate precursor of $\mathrm{GA}_{12}$ ) was metabolized quickly into a variety of compounds including GAs 53, 44, 19, 20, and 17 under both long-day and short-day conditions (Davies et al., 1986). In potato (Solanum tuberosum spp. andigena) shoots, 20 metabolites were detected from the metabolism of $\left[{ }^{14} \mathrm{C}^{-} \mathrm{GA}_{12}\right.$, including GAs 53, 44, 19, 20, 29, 1, and 8 (van den Berg et al., 1995).

In our study, the identification of most of the members in 13hydroxylation pathway (along with the expected existence of $\mathrm{GA}_{5}$ ) strongly suggests that this is the major metabolic pathway in vigorously growing apple shoots. This result is consistent with GA metabolism in vegetative tissues of potato (van den Berg et al., 1995) and most other plant species (Sponsel and Hedden, 2010) but different from that in apple seeds, which favors the production of $\mathrm{GA}_{4}$ and $\mathrm{GA}_{7}$ by the non-13-hydroxylation pathway. However, neither $\mathrm{GA}_{1}$ nor $\mathrm{GA}_{29}$ was identified, indicating the likely predominance of the shift to $\mathrm{GA}_{3}$ following $\mathrm{GA}_{20}$ in the metabolic pathway.

The identification of $\mathrm{GA}_{15}$, an upstream compound that leads to bioactive $\mathrm{GA}_{4}$, may indicate the existence of the nonhydroxylation pathway in apple vegetative tissues. However, neither $\mathrm{GA}_{4}$ nor its precursors $\mathrm{GA}_{24}$ and $\mathrm{GA}_{9}$ were identified in this study, suggesting that instead of going through this pathway, $\mathrm{GA}_{15}$ could be metabolized into $\mathrm{GA}_{44}$ to produce $\mathrm{GA}_{3}$. Putative $\mathrm{GA}_{15}$ was also detected by Motosugi et al. (1996), although without MS identification, together with putative $\mathrm{GA}_{53}, \mathrm{GA}_{44}$, and $\mathrm{GA}_{19}$ in the xylem exudates of 'Fuji' apple on 'Marubakaido' and M.26 rootstocks. The authors suggested this was an indication that both the early hydroxylation and non-hydroxylation pathways functioned in rootstocks. The 
existence of both pathways in apple was also speculated by Zhao et al. (2010), because MdGA20ox1, MdGA3ox1, and $M d G A 2 o x 1$ were able to catalyze GAs of both the 13-hydroxylation and non-hydroxylation pathways in vitro. Indeed, both 13hydroxylated GAs $\left(\mathrm{GA}_{1}, \mathrm{GA}_{3}, \mathrm{GA}_{8}, \mathrm{GA}_{19}\right.$, and $\left.\mathrm{GA}_{20}\right)$ and non-13-hydroxylated GAs $\left(\mathrm{GA}_{4}, \mathrm{GA}_{7}\right.$, and GA9) were identified in seeds of 'Spartan' apple (Steffens et al., 1992). However, it is not clear whether these two pathways function to the same capacity in vegetative tissues.

$\mathrm{GA}_{3}$ was the only bioactive GA detected in our study and has been identified in many other plant species, although is generally not as common as $\mathrm{GA}_{1}$ (Davies, 2010). The $\mathrm{GA}_{3}$

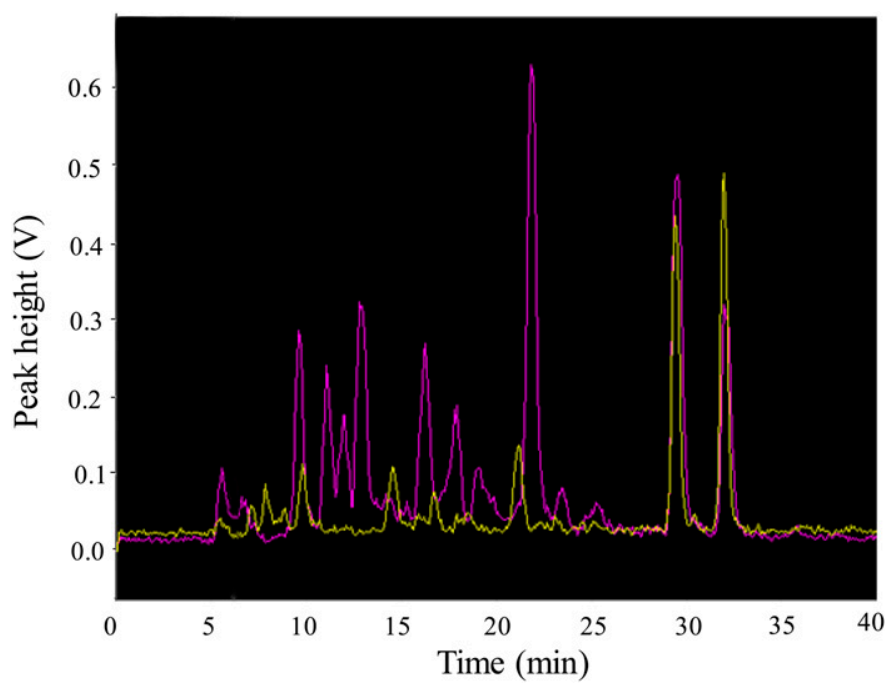

Fig. 6. Overlay high-performance liquid chromatography of metabolites from dwarf (yellow) and standard (magenta) apple shoots of progeny 806 supplied with $\left[{ }^{14} \mathrm{C}\right] \mathrm{GA}_{12}$ for $3 \mathrm{~h}$ through the base of the shoots with the feeding peaks aligned to similar scale. In dwarf seedlings, the feeding peaks are still the most prominent compounds, whereas in standard plants, they are already metabolized into a group of compounds residing in the center of the profile. The detector response, indicating the amount of radioactivity, is in volts.

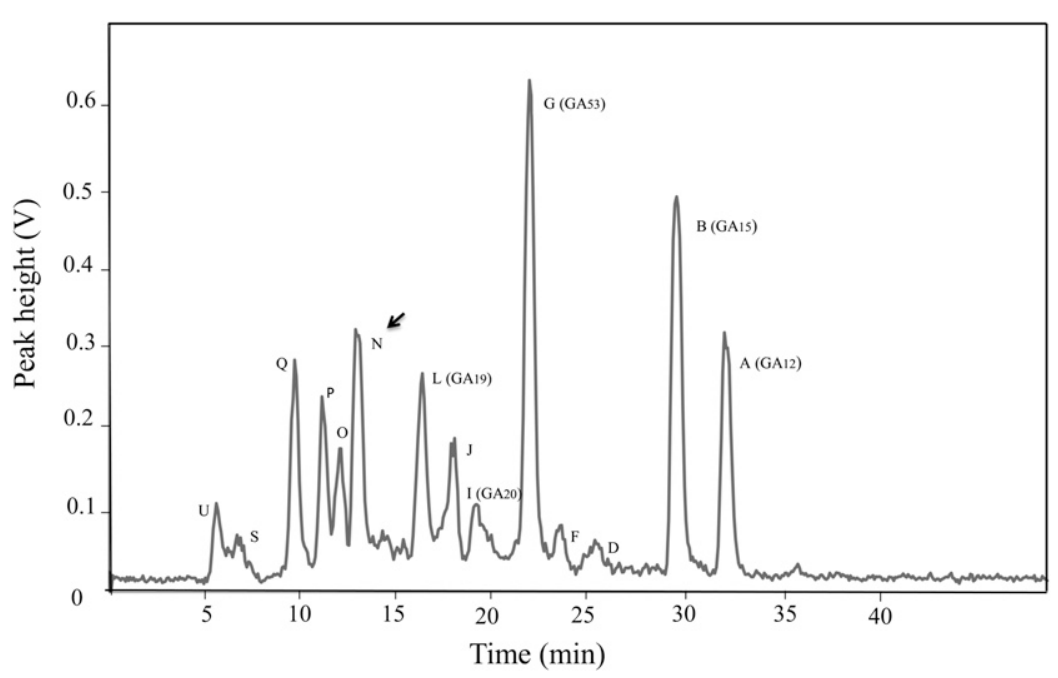

Fig. 7. High-performance liquid chromatograph of metabolites of $\left[{ }^{14} \mathrm{C}\right] \mathrm{GA}_{12}$ in apple shoots of 806 standard plants after feeding for $3 \mathrm{~h}$ through the base of the shoots. The detector response, indicating the amount of radioactivity, is in volts. Peak $\mathrm{N}$ was not found at any time spot of 806 dwarf plants. was not a contamination because it contained both the native and the $\left[{ }^{14} \mathrm{C}\right] \mathrm{GA}_{3}$ MS ions, which can only have been produced from the applied $\left[{ }^{14} \mathrm{C}\right] \mathrm{GA}_{12}$. Low levels of $\mathrm{GA}_{3}$ were also detected by Steffens and Hedden (1992a, 1992b) in the shoot tips of both standard and dwarf phenotypes. Although shoot vigor increased from 806 dwarf to 806 standard to 'Redcort'/ MM.106, the initial appearance (time) of $\mathrm{GA}_{3}$ appeared to be negatively correlated with shoot vigor. The late appearance of $\mathrm{GA}_{3}$ in 806 standard plants and in 'Redcort' can be justified on the basis of feedback regulation (Ross et al., 1999). It could be hypothesized that there were already sufficient bioactive GAs in the shoots, whereas 806 dwarf plants were in a GA-deficient situation, so that $\mathrm{GA}_{3}$ was generated soon after the availability of its upstream precursors, $\mathrm{GA}_{19}$ and $\mathrm{GA}_{20}$. Other bioactive GAs detected in apple by others include $\mathrm{GA}_{1}, \mathrm{GA}_{4}$, and $\mathrm{GA}_{7}$ (Table 1).

Because we failed to detect $\mathrm{GA}_{4}$ or $\mathrm{GA}_{7}$, we conclude that either these compounds was not produced from the applied $\left[{ }^{14} \mathrm{C}\right] \mathrm{GA}_{12}$ or that they were present below our level of detection $\left(\approx 1 \mathrm{ng} \cdot \mathrm{g}^{-1}\right)$, and if present as a radioactive metabolite, their presence was transitory because of rapid further metabolism.

Some of the detected metabolites were neutral rather than acidic, so were likely GA conjugates. Conjugation regulates bioactive GA concentrations, and conjugation to glucose is most common. The presence of GA conjugates was suggested in the metabolites of $\mathrm{GA}_{12}$-aldehyde in pea shoots from the $\mathrm{G} 2$ line (Davies et al., 1986) and in the metabolites of $\mathrm{GA}_{12}$ from potato shoots (van den Berg et al., 1995). To confirm whether these metabolites are GA conjugates, base hydrolysis to yield free GAs would be needed with further purification on HPLC for identification by GC-MS (Koshioka et al., 1983).

$\left[{ }^{14} \mathrm{C}\right] \mathrm{GA}_{12}$ metabolism varied in different plant materials used in this study both in compounds produced and metabolic rates. Although discussion in previous paragraphs suggests that the $3 \beta$-hydroxylation is regulated by the bioactive GAs present in the plant materials, the different rates of $\mathrm{GA}_{19}$ metabolism and accumulation of $\mathrm{GA}_{53}$ in 'Redcort' shoots demonstrate that the three-step 20-oxidation is possibly under feedback control as well. These differences could possibly be attributed to the greater amount of radioactive material applied to the 'Redcort' shoots (7.4 GBq/shoot $=560 \mathrm{pmol}, 190 \mathrm{ng} / \mathrm{shoot})$ as compared with that of 806 shoots $(3.7 \mathrm{GBq} /$ shoot $=280 \mathrm{pmol}, 95 \mathrm{ng} / \mathrm{shoot})$, but the mass of the 'Redcort' shoots (4.0 g) was more than double the mass of the 806 shoots $(1.7 \mathrm{~g})$. Another piece of evidence supporting this is that $\mathrm{GA}_{19}$ and $\mathrm{GA}_{20}$ are the major components previously characterized in vegetative apple tissues with bioactive GAs $\left(\mathrm{GA}_{1}\right.$ and $\mathrm{GA}_{3}$ ) at a much lower level (Koshioka et al., 1985; Steffens and Hedden, 1992a). In pea, both the $3 \beta$-hydroxylation and the last step of 20-oxidation (from $\mathrm{GA}_{19}$ to $\mathrm{GA}_{20}$ ) were feedback-regulated by $\mathrm{GA}_{1}$ (Ross et al., 1999). The fact that in 'Redcort', $\mathrm{GA}_{19}$ increased to $15 \%$ of the total radioactivity, whereas $\mathrm{GA}_{20}$ only increased to $4 \%$ between 6 and 48 h suggests that the last step of 20oxidation is more strongly feedback-regulated than is 3ß-hydroxylation. Faust (1989) also suggested that $\mathrm{GA}_{19}$ is the major GA in apple 

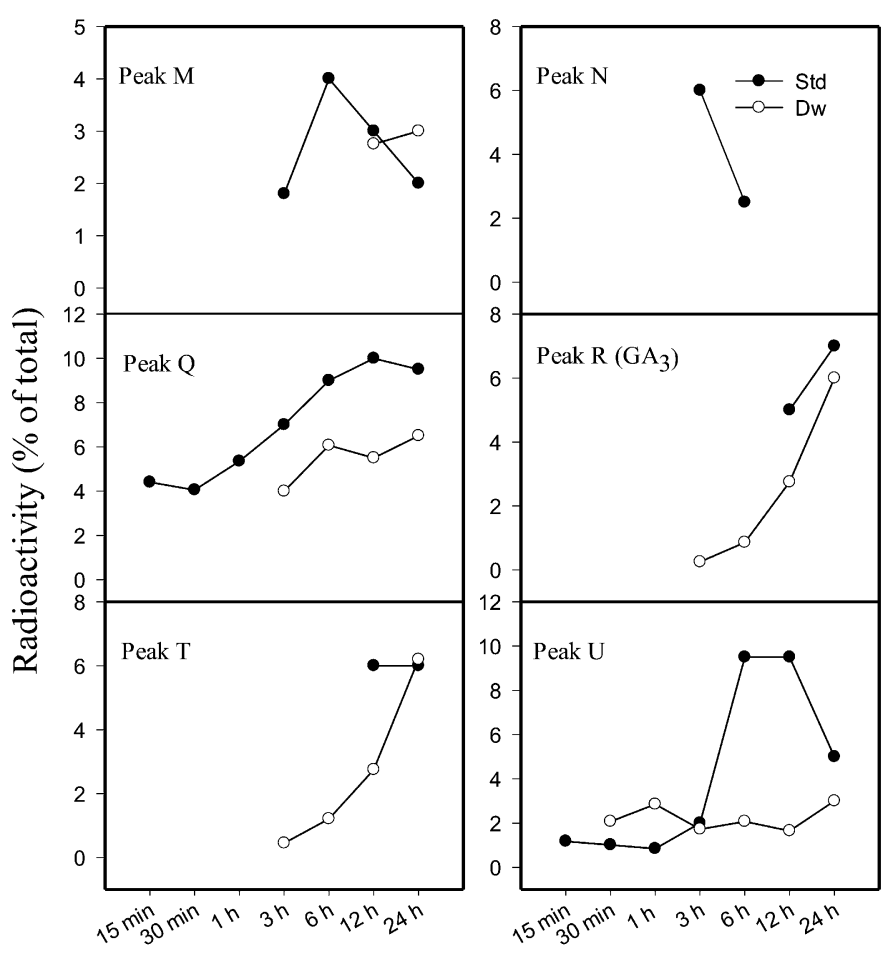

Treatment time

Fig. 8. Comparison of metabolic trends of high-performance liquid chromatography peaks $\mathrm{M}, \mathrm{N}, \mathrm{Q}, \mathrm{R}\left(\mathrm{GA}_{3}\right), \mathrm{T}$, and $\mathrm{U}$ from $\left[{ }^{14} \mathrm{C}_{\mathrm{G}}\right] \mathrm{GA}_{12}$-fed dwarf $(\mathrm{Dw})$ and standard (Std) apple seedlings from progeny 806 .

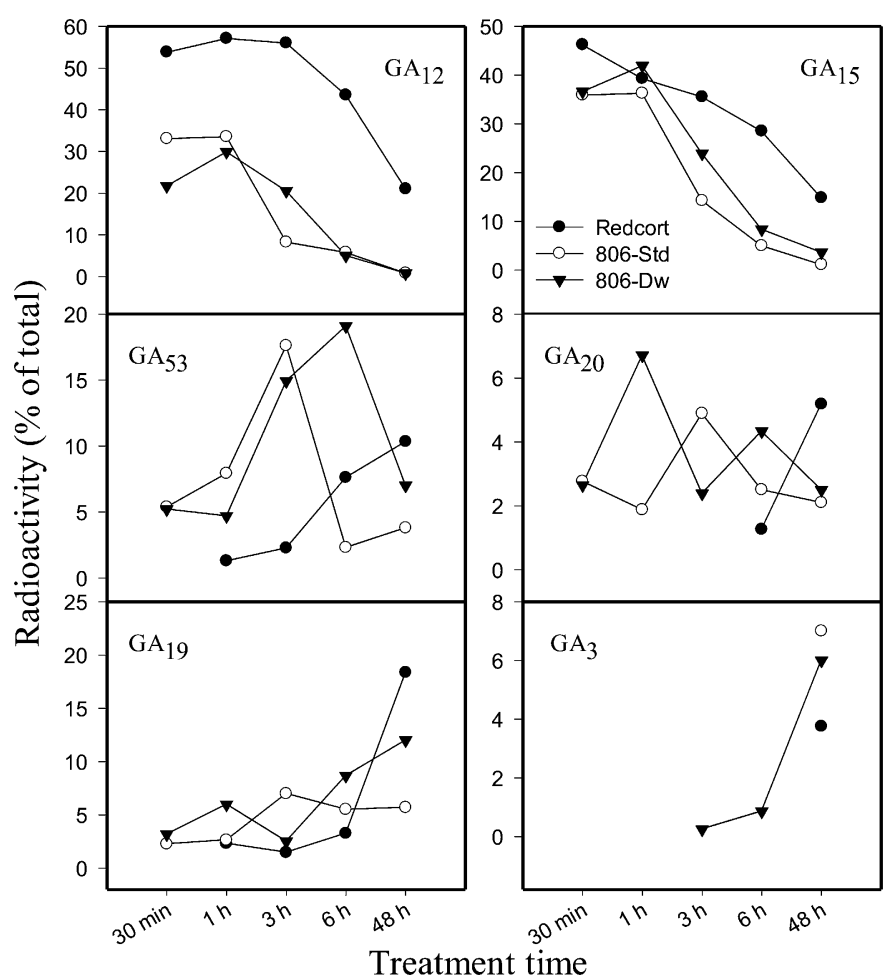

Fig. 9. Comparison of metabolic trends of identified gibberellins in the $\left[{ }^{14} \mathrm{C}_{\mathrm{GA}} \mathrm{G}_{12}\right.$-fed apple shoots from apple cultivar Redcort/MM.106 and 806 standard (Std) and dwarf (Dw) phenotypes.
Table 5. New growth of shoots of dwarf 806 apple plants treated with gibberellin $\left(\mathrm{GA}_{3}\right)$ and control solutions. ${ }^{\mathrm{z}}$

\begin{tabular}{lcccc}
\hline & $\begin{array}{c}\text { Branches } \\
\text { (no.) }\end{array}$ & Total length $(\mathrm{cm})$ & Nodes (no.) & $\begin{array}{c}\text { Internode } \\
\text { length }(\mathrm{cm})\end{array}$ \\
\hline Control & 15 & $11.47 \pm 1.27 \mathrm{a}^{\mathrm{y}}$ & $11.6 \pm 0.80 \mathrm{a}$ & $0.94 \pm 0.06 \mathrm{a}$ \\
Treatment & 11 & $15.25 \pm 1.48 \mathrm{~b}$ & $14.7 \pm 1.00 \mathrm{~b}$ & $1.07 \pm 0.07 \mathrm{a}$ \\
\hline
\end{tabular}

${ }^{\mathrm{z}}$ Measurements were taken 2 weeks after the fifth application.

${ }^{y}$ Means followed by different letters are significantly different by Student's $t$ test at $\alpha=0.05, \mathrm{df}=24$.

vegetative tissues. Therefore, in vigorous-growing apple shoots, the homeostasis and optimal level of bioactive GAs may be partly achieved by the regulation of enzymatic activity.

Another difference for the plant materials used in the study was that 'Redcort' was on vigorous rootstock MM.106, whereas plants from 806 were on their own roots. Transport of GAs is expected between scion and rootstock; although most research results suggest that the major compounds transported are non-bioactive GAs, the direction of the transport remains a matter of a debate (Bulley et al., 2005; Lochard and Schneider, 1981; Motosugi et al., 1996). In both pea and potato plants, $\mathrm{GA}_{20}$ is the major transported GA (Prat, 2010; Proebsting et al., 1992). However, $\mathrm{GA}_{20}$ was not identified in the xylem exudates from 'Fuji' apple, whereas $\mathrm{GA}_{19}$ was identified (Motosugi et al., 1996). The concentration of $\mathrm{GA}_{19}$ was also shown to increase with increasing rootstock vigor in the xylem sap of grafted apples in the growing season (van Hooijdonk et al., 2011). Thus, there seems to be a variation in which of the intermediate GAs is the transported $\mathrm{GA}$ in different species with $\mathrm{GA}_{19}$ being the major transported GA in apple. This would support earlier discussions that the last step of 20-oxidation is more strictly regulated than $3-\beta$ hydroxylation. A study of the transport of radiolabeled GAs in grafted apples would aid in this clarification.

In progeny 806 , the same GAs were identified in dwarf and standard phenotypes, consistent with the findings of Steffens and Hedden (1992a), although $\mathrm{GA}_{1}, \mathrm{GA}_{29}$, and $\mathrm{GA}_{8}$ were not detected in our study. Peak N, which was not identified as to GA, is the only metabolite detected in standard plants but not in dwarf plants. N elutes earlier than $\mathrm{GA}_{19}$, so it is more polar and may be a bioactive GA downstream of $\mathrm{GA}_{19}$. However, its transient presence ( 3 to $6 \mathrm{~h}$ ) suggests it is more likely to be a rapidly metabolized intermediate.

Despite similar metabolic trends, 806 dwarf plants metabolized $\mathrm{GA}_{12}$ at approximately half the speed of that of standard plants, perhaps as a result of the low bioactivity of certain enzymes in the GA biosynthesis pathway or may be the result of the low vigor. Looney et al. (1988) also reported that the bioactivity of polar GAs in shoot tips from compact growth strains of 'McIntosh' was significantly lower than from the normal strains. The dioxygenases GA-20ox, GA-3ox, and GA-2ox are often encoded by multigene families (Sponsel and Hedden, 2010), so defects of certain enzymes in dwarf plants may be covered by other gene family members, which may have overlapping expression or can be transported from other parts of the plant and result in leaky mutants. The differences in metabolism between 'Redcort' and progeny 806 could also be attributed to cultivar differences as well as physiological status of the plant materials such as flowering and fruiting ('Redcort') vs. juvenile stage (non-flowering) (806).

We conclude that dwarf phenotype in 806 is not caused by lack of certain GAs in the biosynthesis pathway downstream of 
$\mathrm{GA}_{12}$, although this does not exclude the possibility of impairment before $\mathrm{GA}_{12}$. In contrast to Steffens et al. (1989b), where dwarf apple plants were not rescued by exogenous $\mathrm{GA}_{3}, \mathrm{GA}$ application in our study did increase internode number but had no effect on internode length. Because GAs can have effects both on cell division and cell elongation (Davies, 2010), it remains a possibility that insufficient GAs are produced in dwarf plants, although clearly that is not the main cause of dwarfism. Alternatively, dwarfism can be caused by a blockage in the GA signaling pathway or by defects in other plant hormones that regulate plant form such as brassinosteroids or strigolactone (Pereira-Lorenzo et al., 2009; Rameau, 2010).

\section{Literature Cited}

Alston, F.H. 1976. Dwarfing and lethal genes in apple progenies. Euphytica 25:505-514.

Brown, S. 2012. Apple, p. 329-367. In: Badenes, M.L. and D.H. Byrne (eds.). Fruit breeding. Springer-Verlag, New York, NY.

Bulley, S.M., F.M. Wilson, P. Hedden, A.L. Phillips, S.J. Croker, and D.J. James. 2005. Modification of gibberellin biosynthesis in the grafted apple scion allows control of tree height independent of the rootstock. Plant Biotechnol. J. 3:215-223.

Byrne, D.H. 2012. Trends in fruit breeding, p. 3-36. In: Badenes, M.L. and D.H. Byrne (eds.). Fruit breeding. Springer-Verlag, New York, NY. Costes, E. and E. García-Villanueva. 2007. Clarifying the effects of dwarfing rootstock on vegetative and reproductive growth during tree development: A study on apple trees. Ann. Bot. (Lond.) 100:347357.

Costes, E., P. Lauri, and J.L. Regnard. 2006. Analyzing fruit tree architecture: Implications for tree management and fruit production. Hort. Rev. 32:1-61.

Curry, E. 2012. Increase in epidermal planar cell density accompanies decreased russeting of 'Golden Delicious' apples treated with gibberellin $\mathrm{A}_{4+7}$. HortScience 47:232-237.

Davies, P.J. 2010. The plant hormones: Their nature, occurrence and function, p. 1-15. In: Davies, P.J. (ed.). Plant hormones: Biosynthesis, signal transduction, action! Revised 3rd Ed. Springer-Verlag, Dordrecht, The Netherlands.

Davies, P.J., P.R. Birnberg, S.L. Maki, and M.L. Brenner. 1986. Photoperiod modification of $\left[{ }^{14} \mathrm{C}\right]$ gibberellin A12 aldehyde metabolism in shoots of pea, line G2. Plant Physiol. 81:991-996.

Di Lella, S., A. Elli, T. Eccher, and H. Hajnajari. 2006. Gibberellin content of apple fruit as affected by genetic and environmental factors. Acta Hort. 774:221-228.

El-Sharkawy, I., W. El Kayal, D. Prasath, H. Fernández, M. Bouzayen, A. Svircev, and S. Jayasankar. 2012. Identification and genetic characterization of a gibberellin 2-oxidase gene that controls tree stature and reproductive growth in plum. J. Expt. Bot. 63:12251239.

Faust, M. 1989. Factors determining size of fruit trees, p. 235-273. In: Faust, M. (ed.). Physiology of temperate zone fruit trees. Wiley, New York, NY.

Foster, T., C. Kirk, W.T. Jones, A.C. Allan, R. Espley, S. Karunairetnam, and J. Rakonjac. 2007. Characterisation of the DELLA subfamily in apple (Malus $\times$ domestica Borkh.). Tree Genet. Genomes 3:187-197.

Gaskin, P. and J. MacMillan. 1991. GC-MS of the gibberellins and related compounds: Methodology and a library of spectra. Cantock's Enterprises, Bristol, UK.

Gmelin, L. 1849. Phlorizin, p. 11-16. In: Hand-book of chemistry. Vol. 16. Cavendish Soc., London, UK.

Gosch, C., H. Halbwirth, and K. Stich. 2010. Phloridzin: Biosynthesis, distribution and physiological relevance in plants. Phytochemistry 71:838-843.

Guitton, B., J.J. Kelner, R. Velasco, S.E. Gardiner, D. Chagné, and E. Costes. 2012. Genetic control of biennial bearing in apple. J. Expt. Bot. 63:131-149.
Halińska, A., P.J. Davies, J.W. Lee, and Y.X. Zhu. 1989. Further identification of endogenous gibberellins in the shoots of pea, line G2. Plant Physiol. 91:1255-1258.

Halińska, A. and S. Lewak. 1987. Free and conjugated gibberellins in dormancy and germination of apple seeds. Physiol. Plant. 69:523530.

Kittikorn, M., N. Shiraishi, K. Okawa, H. Ohara, M. Yokoyama, O. Ifuku, S. Yoshida, and S. Kondo. 2010. Effect of fruit load on 9, 10-ketol-octadecadienoic acid (KODA), GA and jasmonic acid concentrations in apple buds. Sci. Hort. 124:225-230.

Koshioka, M., J. Harada, K. Takeno, M. Noma, T. Sassa, K. Ogiyama, J. Taylor, S. Rood, R. Legge, and R. Pharis. 1983. Reversed-phase C18 high-performance liquid chromatography of acidic and conjugated gibberellins. J. Chromatography 256:101-115.

Koshioka, M., J. Taylor, G. Edwards, N. Looney, and R. Pharis. 1985. Identification of gibberellins A19 and A20 in vegetative tissue of apple. Agr. Biol. Chem. 49:1223-1226.

Kusaba, S., C. Honda, and Y. Kano-Murakami. 2001. Isolation and expression analysis of gibberellin 20-oxidase homologous gene in apple. J. Expt. Bot. 52:375-376.

Lang, A. 1990. Xylem, phloem and transpiration flows in developing apple fruits. J. Expt. Bot. 41:645-651.

Lewak, S. 2011. Metabolic control of embryonic dormancy in apple seed: Seven decades of research. Acta Physiol. (Oxf.) 33:1-24.

Liang, M., J. Zhu, and H. Dai. 2011. Cloning and expression analyzing of MdGAI gene of columnar apples. Acta Hort. 38:1969-1975.

Lochard, R. and G. Schneider. 1981. Stock and scion growth relationships and the dwarfing mechanism in apple. Hort. Rev. 3:315-375.

Looney, N., J. Taylor, and R. Pharis. 1988. Relationship of endogenous gibberellin and cytokinin levels in shoot tips to apical form in four strains of 'McIntosh' apple. J. Amer. Soc. Hort. Sci. 113:395-398.

Looney, N.E., R.P. Pharis, and M. Noma. 1985. Promotion of flowering in apple trees with gibberellin A4 and C-3 epi-gibberellin A4. Planta 165:292-294.

Miller, S.S. and T. Tworkoski. 2003. Regulating vegetative growth in deciduous fruit trees. Plant Growth Regulat. Soc. Amer. Qrtly. 31:8-46.

Motosugi, H., T. Nishijima, N. Hiehata, M. Koshioka, and A. Sugiura. 1996. Endogenous gibberellins in the xylem exudate from apple trees. Biosci. Biotechnol. Biochem. 60:1500-1502.

Oyama, N., T. Yamauchi, H. Yamane, N. Murofushi, M. Agatsuma, M. Pour, and L. Mander. 1996. Identification of gibberellins and 9, 15cyclogibberellins in developing apple seeds. Biosci. Biotechnol. Biochem. 60:305-308.

Pereira-Lorenzo, S., A. Ramos-Cabrer, and M. Fischer. 2009. Breeding apple (Malus $\times$ domestica Borkh.), p. 33-81. In: Jain, S.M. and P.M. Priyadarshan (eds.). Breeding plantation tree crops: Temperate species. Springer-Verlag, New York, NY.

Prat, S. 2010. Hormonal and daylength control of potato tuberization, p. 574-596. In: Davies, P.J. (ed.). Plant hormones: Biosynthesis, signal transduction, action! Revised 3rd Ed. Springer-Verlag, Dordrecht, The Netherlands.

Proebsting, W.M., P. Hedden, M.J. Lewis, S.J. Croker, and L.N. Proebsting. 1992. Gibberellin concentration and transport in genetic lines of pea: Effects of grafting. Plant Physiol. 100:1354-1360.

Rameau, C. 2010. Strigolactones, A novel class of plant hormone controlling shoot branching. C. R. Biol. 333:344-349.

Ramírez, H., J. Torres, A. Benavides, J. Hernández, and V. Robledo. 2004. Fruit bud initiation in apple cv Red Delicious linked to gibberellins and cytokinins. Revista de la Sociedad Química de Mexico 48:7-10.

Richards, D., W.K. Thompson, and R.P. Pharis. 1986. The influence of dwarfing interstocks on the distribution and metabolism of xylemapplied $\left[{ }^{3} \mathrm{H}\right]$ gibberellin A4 in apple. Plant Physiol. 82:1090-1095.

Ross, J.J., A.K. MacKenzie-Hose, P.J. Davies, D.R. Lester, B. Twitchin, and J.B. Reid. 1999. Further evidence for feedback regulation of gibberellin biosynthesis in pea. Physiol. Plant. 105:532538. 
Schmidt, T., J. McFerson, D. Elfving, and M. Whiting. 2010. Practical gibberellic acid programs for mitigation of biennial bearing in apple. Acta Hort. 884:663-670.

Seleznyova, A., T. Thorp, M. White, S. Tustin, and E. Costes. 2003. Application of architectural analysis and AMAPmod methodology to study dwarfing phenomenon: The branch structure of 'Royal Gala' apple grafted on dwarfing and non-dwarfing rootstock/interstock combinations. Ann. Bot. (Lond.) 91:665-672.

Sinska, I. and S. Lewak. 1970. Apple seed gibberellins. Physiol. Veg. 8:661-667.

Sinska, I. and S. Lewak. 1977. Is the gibberellin A4 biosynthesis involved in the removal of dormancy in apple seeds? Plant Sci. Lett. 9:163-170.

Sponsel, V.M. and P. Hedden. 2010. Gibberellin biosynthesis and inactivation, p. 63-94. In: Davies, P.J. (ed.). Plant hormones: Biosynthesis, signal transduction, action! Revised 3rd Ed. SpringerVerlag, Dordrecht, The Netherlands.

Steffens, G. and P. Hedden. 1992a. Comparison of growth and gibberellin concentrations in shoots from orchard-grown standard and thermosensitive dwarf apple trees. Physiol. Plant. 86:544-550.

Steffens, G. and P. Hedden. 1992b. Effect of temperature regimes on gibberellin levels in thermosensitive dwarf apple trees. Physiol. Plant. 86:539-543.

Steffens, G., F. Jacobs, and M. Engelhaupt. 1989a. Thermosensitive genetic dwarfs of apple. Physiol. Plant. 76:368-374.

Steffens, G., F. Jacobs, and M. Engelhaupt. 1989b. Response of genetic dwarf apple plants to $\mathrm{GA}_{3}$. Physiol. Plant. 76:375-378.

Steffens, G., J. Lin, A. Stafford, J. Metzger, and J. Hazebroek. 1992. Gibberellin content of immature apple seeds from paclobutrazoltreated trees over three seasons. J. Plant Growth Regul. 11:165-170.

Stephan, M., F. Bangerth, and G. Schneider. 1997. Transport and metabolism of the gibberellins A1, A2, A3 and A4 after application to developing apple fruits of Malus domestica cv. 'Jonagold'. Acta Hort. 463:113-120.

Stephan, M., F. Bangerth, and G. Schneider. 1999. Quantification of endogenous gibberellins in exudates from fruits of Malus $\times$ domestica. Plant Growth Regulat. 28:55-58.

Tromp, J. 1982. Flower-bud formation in apple as affected by various gibberellins. J. Hort. Sci. 57:277-282.

van den Berg, J., P. Davies, E. Ewing, and A. Halinska. 1995. Metabolism of gibberellin A12 and A12-aldehyde and the identification of endogenous gibberellins in potato (Solanum tuberosum spp. andigena) shoots. J. Plant Physiol. 146:459-466.

van Hooijdonk, B., D. Woolley, I. Warrington, and S. Tustin. 2005. Architectural development of 'Royal Gala' apple scions in response to rootstock, root restriction, and benzylaminopurine. Acta Hort. 727:561-568.

van Hooijdonk, B., D. Woolley, I. Warrington, and S. Tustin. 2011. Rootstocks modify scion architecture, endogenous hormones, and root growth of newly grafted 'Royal Gala' apple trees. J. Amer. Soc. Hort. Sci. 136:93-102.

Xu, H., W. Zhang, M. Li, T. Harada, Z. Han, and T. Li. 2010. Gibberellic acid insensitive mRNA transport in both directions between stock and scion in Malus. Tree Genet. Genomes 6:10131019.

Zhao, H., J. Dong, and T. Wang. 2010. Function and expression analysis of gibberellin oxidases in apple. Plant Mol. Biol. Rpt. 28: 231-238.

Zhu, L., X. Li, and M. Welander. 2008. Overexpression of the Arabidopsis gai gene in apple significantly reduces plant size. Plant Cell Rpt. 27:289-296.

Zhu, Y.X., P.J. Davies, and A. Halinska. 1988. Gibberellin A12 and gibberellin A12-7-aldehyde as endogenous compounds in developing seeds of Pisum sativum. Phytochemistry 27:2549-2552. 

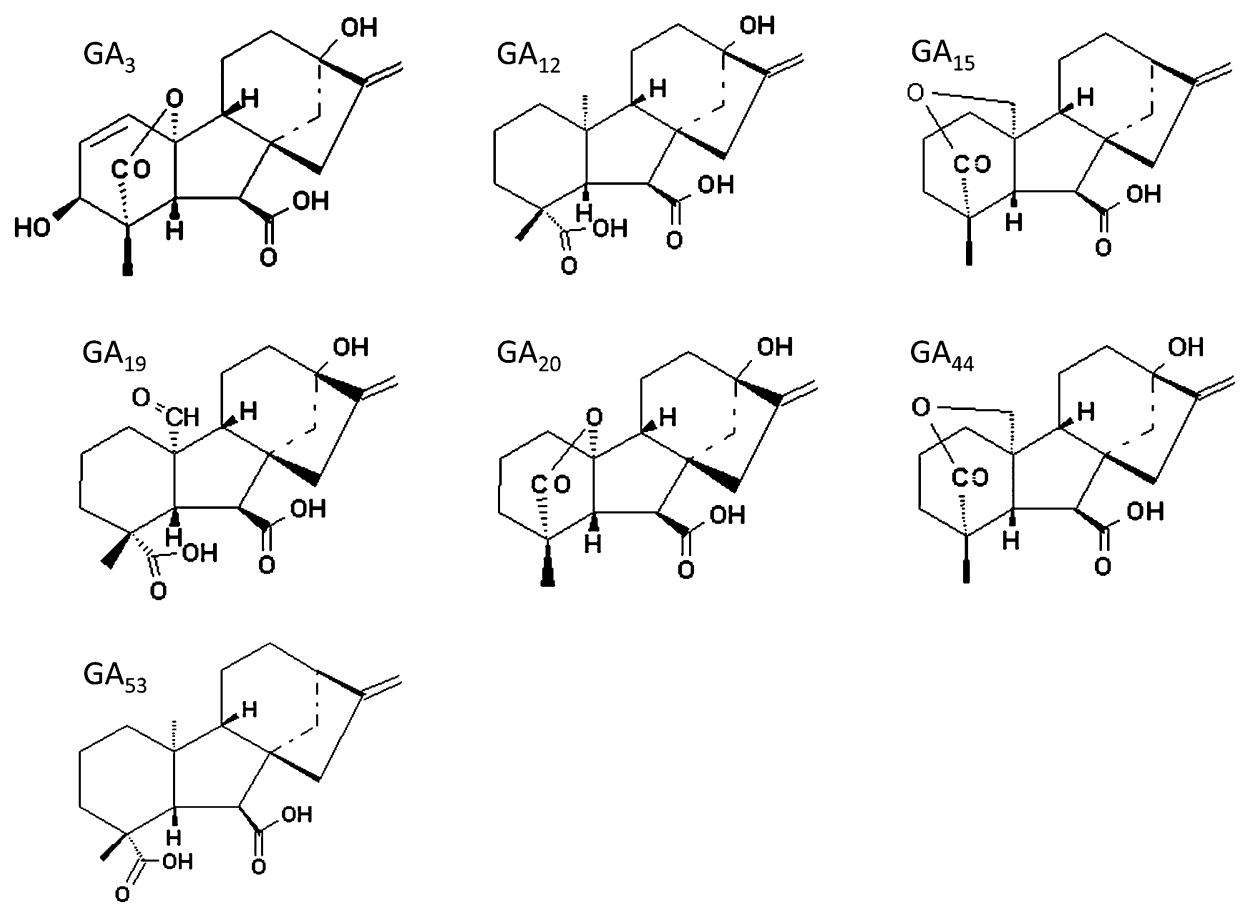

Supplemental Fig. 1. Structures of gibberellins found in apple shoots by gas chromatography-mass spectroscopy. 